\title{
Learning and linking for invasive species management
}

\author{
Sally W. Nourani ${ }^{1}$, Marianne E. Krasny ${ }^{1}$ and Daniel J. Decker ${ }^{2}$
}

\begin{abstract}
Invasive species can create economic and safety concerns. Responding to invasive species requires communication of research, localized management, and collaboration across jurisdictional boundaries. We examined the use of adaptive comanagement in three New York counties to mitigate the impacts of emerald ash borer, a wood-boring beetle that causes widespread death of ash trees. We assessed learning along three typologies (cognitive, normative, and relational), linking (through network analysis), and connections of learning and linking to management outcomes. Findings indicate that knowledge networks were built through task forces that brought together local and state government, university, and private stakeholders. In addition, this study suggests types of learning that are needed for stakeholders to respond to invasive species management.
\end{abstract}

Key Words: adaptive comanagement; invasive species; knowledge networks; learning; social learning

\section{INTRODUCTION}

Decisions about invasive species management tend to be complex with competing priorities and multiple stakeholder groups (Donlan and Martin 2004). Eradication or control of invasive species often demands actions that span jurisdictions and property boundaries, and action or inaction in one place affects the outcomes elsewhere; therefore, coordinated management is needed (Epanchin-Niell et al. 2010). Although the impacts, stakeholder groups, and decisions around management vary based on the species, adaptive and collaborative approaches may aid in the eradication, control, or mitigation of invasive species.

Adaptive management has been used in the detection of new invasive species (Cook et al. 2010) to address information gaps at the beginning of invasive species management programs and to assess the effectiveness of management strategies (Buckley 2008). Comanagement has outperformed state management in protecting the soft-shelled clam fisheries in Maine from a green crab invasion (McClenachan et al. 2015). Adaptive and collaborative approaches to invasive plants have been used at landscape scales in the Southeastern USA and Great Basin, USA (Miller and Schelhas 2008, Schelhas et al. 2012); however, little is known about how they produce outcomes for management.

Adaptive comanagement (ACM) combines the "learning function" of adaptive management and the "linking function" of comanagement (Plummer et al. 2012). The generation of new ecological knowledge through learning-by-doing (adaptive management), and social or institutional learning (collaboration, joint decision making, and multistakeholder arrangements) are both necessary parts of ACM (Armitage et al. 2008). The linking function of ACM makes connections between stakeholders horizontally (among public, private, nonprofit, and academic sectors) and vertically among levels of government (Plummer et al. 2012).

We investigated ACM in the context of the emerald ash borer (EAB), an invasive beetle originating in Asia causing widespread mortality of multiple species of the genus Fraxinus, commonly known as ash trees, across North America and Russia, and moving rapidly toward Europe. Like other invasive species, EAB has multiple types of impacts: social, economic, and ecological. A 2011 economic analysis concluded that the financial impact of EAB was borne by homeowners and local governments via local expenditures and losses to property value (Aukema et al. 2011). The EAB causes $100 \%$ mortality of all ash within $10-20$ years of introduction (Smitley et al. 2008). Limited options for controlling ash mortality suggest that the object of adaptation or learning around $\mathrm{EAB}$ may not be the ecosystem dynamics, but rather the institutional structures needed to manage rapid decision making at a local level.

To investigate the use of $\mathrm{ACM}$ for $\mathrm{EAB}$ management, the first author conducted case studies of three county-level task forces in New York State, USA, which were set up to assist governments, organizations, and private citizens prepare for and respond to EAB impacts. Our overarching research question is: how can learning and linking in a local task force facilitate management planning and action? To address this question, we examined types of learning that occurred in the task forces; task force impact on network formation; and task force influence on municipal and county ash management.

\section{LITERATURE REVIEW}

Environmental crises such as invasive species can trigger social reorganization, providing an opportunity for new forms of collective action and social learning (Olsson et al. 2004). To integrate information held by different organizations and agencies, innovative arrangements are needed that cross scales and levels (Cash et al. 2006).

\section{The invasive species knowing-doing gap}

A gap has been identified between invasive species research and management (Esler et al. 2010, Matzek et al. 2014). Managers who deal with invasive species are more likely to rely on their own experience and management options promoted by private firms (Lavoie and Brisson 2015). Creating platforms for direct contact between managers and researchers may help address this gap because it enables managers to translate scientific information into terms that make sense in their own context, a prerequisite for knowledge utilization (Lauber and Brown 2006, Bayliss et al. 2012, Matzek et al. 2014). In water supply management, direct, 
ongoing contact between scientists and policymakers increased the utilization of research in decision making (Crona and Parker 2011). Adaptive comanagement has been used to systematically connect scientists to land owners, managers, and policymakers dealing with invasive plants, but the impact of these approaches on research utilization has not yet been addressed (Miller and Schelhas 2008, Schelhas et al. 2012).

\section{Learning}

Learning has emerged as a crucial consideration when organizations and institutions lack the capacity to deal with the uncertainty and complexity of the natural resource management issues they face (Lee 1999, Plummer et al. 2014). Learning in ACM draws from adaptive management (Holling 1978), adaptive capacity (Walker et al. 2002, Olsson et al. 2004, Fabricius et al. 2007), and social learning (Armitage et al. 2008, Plummer et al. 2012). Social learning, a process that occurs through knowledge sharing and joint learning practices, generates new, shared knowledge and leads to changes in practice at an individual, network, and system level (Rodela 2011, Ensor and Harvey 2015). Social learning can empower stakeholders to respond to a disturbance, build consensus, and take adaptive actions (Lebel et al. 2010). Although learning can occur among individuals and groups (Plummer et al. 2007), parsing who is learning and what is being learned is challenging (Armitage et al. 2008, Reed et al. 2010). Baird et al.'s (2014) framework includes types of learning that operate at an individual and group level, including cognitive learning (the acquisition of new or modification of existing knowledge); normative (changes in norms, values, or paradigms, or a convergence of views); and relational (increases in trust, cooperation, and communication).

\section{Linking and networks}

Originally associated with legally mandated arrangements to resolve conflicts between government and user groups, comanagement has expanded to encompass multiple forms of linking between levels of government and public and private groups (Berkes 2009). Comanagement enables managers and scientists to exchange perspectives and engage with different types of knowledge (Wollenberg et al. 2007), sometimes facilitated by bridging organizations (Crona and Parker 2012, Plummer et al. 2012). Examining structural characteristics of social networks can provide insights on generation and diffusion of different types of knowledge and the mobilization of resources. The presence of dense social relations among actors is thought to promote trust, reduce conflict, and facilitate collaboration and learning, albeit excessively high tie density can produce homogenization, stifling innovation, and can reduce adaptive capacity (Bodin et al. 2006, Bodin and Crona 2009, Plummer et al. 2014). Ties that cross organizational boundaries, often called bridging ties, can contribute to ACM by allowing members to access additional information and to overcome social norms within their own organization that may inhibit action (Burt 2003, Newman and Dale 2005). Networks that cross scales and sectors increase adaptive capacity (Olsson et al. 2004, Pahl-Wostl 2009).

\section{METHODS}

\section{Conceptual framework}

Our approach is informed by Plummer et al.'s (2014) diagnostic framework for ACM, which enables cross-case comparison by investigating the components of ACM: (1) setting; (2) activities and practices; (3) learning and networks; and (4) connections of these components to outcomes. We examined learning along three typologies: cognitive, normative, and relational, which function at both the individual and collective levels (Baird et al. 2014). To assess the linking or collaboration component of ACM, we looked for new links among participants. We defined outcomes in terms of results, i.e., the tangible and intangible products that arose from the ACM initiative (Plummer et al. 2014). We evaluated management plans, management actions, cocreated maps, documents, and events as tangible results, and new partnerships, new experience with shared learning, new interest in collaboration, and greater adaptive capacity as intangible results. We also documented activities and practices and contextual characteristics of each case study location.

\section{Research setting and case selection}

This research was set in New York State where tens of thousands of dead and dying ash trees are found along city streets and in forests. Cornell Cooperative Extension and the New York State Department of Conservation formed EAB task forces to assist county and municipal governments and other stakeholders prepare for and respond to EAB. Task force membership included state and county agency personnel, municipal representatives, land managers, professional arborists and tree-care companies, utility company personnel, and citizen volunteers. The first author coordinated communication among the EAB task forces prior to and during this study, which provided insights and influenced the study design. Initial task force meetings took place in eight locations around New York whereas subsequent meetings occurred in five county or multicounty areas. The first author chose three task forces to include as cases in this study based on two criteria: regular task force meetings for more than two years to increase the likelihood that there would be outcomes to study and a mixture of task forces in rural and urban counties to examine ACM in different social and institutional settings.

\section{Data collection}

We used a multicase case study approach (Yin 2003) to explore the following theoretical proposition: a task force leads to positive outcomes for invasive species management through two mechanisms: (1) stimulating learning among stakeholders about the invasive species and management options, and (2) facilitating communication between stakeholders from multiple levels of government and sectors of society. The three cases (Table 1) represent a mixture of urban and rural settings and differences in the intensity of EAB infestation. Case 1 includes one small city (population of 23,000) and towns and villages with large amounts of open forest. Cases 2 and 3 include a large city surrounded by suburbs. The EAB impacts were most advanced in Case 1; Case 2 had no known EAB infestation when the task force began but a small infestation was discovered during the study period; and Case 3 represents a middle between these extremes. The spatial extent of infestations is an area within a polygon of infested trees, with potentially healthy trees in between, and infestations span county borders. Intensity is used to describe infestations according to the rate of tree decline and death.

To develop the case studies, the first author conducted a learning assessment and network survey via Qualtrics ( $\mathrm{N}=67,63 \%$ response rate overall; Table 2$)$, in-depth interviews $(\mathrm{N}=12$; see 
Appendix 1 for survey instrument and interview guide), and document analysis. Survey recipients were task force members who had attended two or more meetings, as a minimum threshold for collaboration and to distinguish the experience from an informational event. The learning questions (cf. Plummer et al. 2017) used Likert scales to assess respondents' self-perceptions of cognitive, normative, and relational learning, whereas network questions asked task force members to indicate how frequently they had contact with every other member prior to the task force (retrospectively) and within the last year, generating a whole network data set. Survey recipients were also asked to identify up to 10 individuals or organizations they went to for EAB information beyond the list of names provided, an egocentric data set, allowing us to verify that all important members of the task force were identified (Marsden 1990) and to examine who else was providing information to task force members, (i.e., researchers, state or federal agencies, pesticide distributors). Open-ended survey questions, semistructured interviews, and meeting notes were used to assess the influence of the task force on municipal and county ash management activities (tree inventories, management plans, tree removals, pesticide treatments). We selected interviewees who (1) would be likely to know what planning or management was being conducted by county and municipal agencies, and (2) were engaged with the task force from the beginning (to give feedback on processoriented outcomes). Where the initial interviewees did not have clear information on ash management by the county, follow-up interviews were conducted with additional county managers. The intent of the interviews was not an overall assessment of the efficacy of the task forces, but to determine what municipal and county management occurred in connection with task force participation, and how.

Table 1. Background information on case study locations.

\begin{tabular}{lccc}
\hline \hline & Case 1 & Case 2 & Case 3 \\
\hline Area of county (square miles) & 1161 & 806 & 1227 \\
Total population & 180,998 & 468,387 & 919,866 \\
Number of municipalities & 27 & 35 & 42 \\
$\begin{array}{l}\text { Year emerald ash borer (EAB) discovered } \\
\text { in county }\end{array}$ & 2010 & 2013 & 2011 \\
$\begin{array}{l}\text { Estimated size of infested area in 2015 } \\
\text { (square miles) }\end{array}$ & 1218 & 121 & 1110 \\
\hline
\end{tabular}

Table 2. Number of task force members surveyed and interviewed and response rate by case.

\begin{tabular}{lccc}
\hline \hline & Case 1 & Case 2 & Case 3 \\
\hline Number of task force members & 16 & 24 & 27 \\
Response rate & $50 \%$ & $68 \%$ & $70 \%$ \\
Number of interviews & 5 & 3 & 3 \\
\hline
\end{tabular}

Interviews included two sections: (1) tangible results, i.e., information on ash management plans and actions from the county and every municipality in the county, and (2) intangible results, i.e., new partnerships, actions these partnerships produced. Probing questions were asked to reveal how attendance at a task force meeting influenced management decisions, i.e., received information, proposed management actions and received feedback, collaboration on grant proposals. The first author compiled meeting notes from each task force from their formation in 2011 to the end of the study period in 2015 to examine what type of information was exchanged or produced, expressions of shared goals or objectives, and joint activities undertaken.

\section{Data analysis}

We calculated scores for each learning typology by averaging responses by learning type and by producing individual level cognitive, normative, and relational scores. Cronbach's alpha was used to assess how well the component statements fit together with the following results: cognitive items 0.75 , normative items 0.69 , and relational items 0.78 . A Cronbach's alpha score of 0.70 indicates that the items reliably fit together in a group. We also conducted summary statistics on individual survey items and examined where responses differed between cases. We used centrality to analyze network structure and formation including "in-degree," the number of ties to each individual and "outdegree," the number ties directed from individuals to other task force members (Hanneman and Riddle 2005, Prell 2011). We used in-degree centrality (IDC) to characterize the whole network because it is more stable than other network metrics when using an incomplete data set (cf. Costenbader and Valente 2003). To assess the formation of new contacts by task force members, we computed the difference between number of ties each individual had to other task force members prior to and after the task force (out-degree centrality) and reported mean out-degree centrality. Using the egocentric network data, we recorded all organizations or individuals named by task force members as sources of information and then identified the connections to researchers. These data are not included in the network maps or IDC, but we reported the who task force members cited as sources of information. We used R (McFarland et al. 2010) to calculate degree centrality, and UCINET for network maps (Borgatti et al. 2002).

The first author examined how the task forces catalyzed management actions among members and other stakeholders (some of whom did not directly participate in the task force) producing categories of interaction for each municipality, e.g., no interaction, attended a training session, attended task force meetings, received information from a task force member about an aspect of management, asked for feedback on management plans in task force meetings, or undertook joint activities such as applying for grants. These categories were based on information from meeting attendance records, meeting notes, and interviews. Transcripts from the second portion of the interviews, which explored relational outcomes, e.g., new partnerships, new cooperative undertakings to address EAB, and whether these partnerships would extend past the task force, were coded to identify emergent themes. Using Nvivo, the first author conducted first and second phase coding; attached labels to transcript text; reread, combined, and refined themes; and wrote analytical memos for each case to summarize themes identified and supporting evidence (Saldana 2013). Emergent coding was also used on meeting notes, resulting in the following categories: research communication, i.e., expert presentations, distribution of publications, and webinars; collective goal setting; joint actions; information on EAB monitoring; and municipal and county ash management activities. The names of the counties, 
Table 3. Learning scores averaged by case (and standard deviation) and responses to selected individual survey items averaged by case to illustrate learning typologies (full survey instrument in Appendix I). Score is based on a five-point scale (1-strongly disagree, 2disagree, 3-neutral, 4-agree and 5-strongly agree). Sample sizes are lower for learning data due to incomplete survey responses.

\begin{tabular}{|c|c|c|c|c|}
\hline $\begin{array}{l}\text { Learning } \\
\text { types }\end{array}$ & Learning scores and selected survey items & $\begin{array}{c}\text { Case } 1 \\
\mathrm{n}=7\end{array}$ & $\begin{array}{l}\text { Case } 2 \\
\mathrm{n}=14\end{array}$ & $\begin{array}{l}\text { Case } 3 \\
\mathrm{n}=16\end{array}$ \\
\hline \multicolumn{5}{|c|}{ Cognitive Learning } \\
\hline & Cognitive Score & $4.64(0.44)$ & $4.21(0.69)$ & $4.20(0.47)$ \\
\hline \multicolumn{5}{|c|}{ My understanding of.... increased } \\
\hline & ecological impacts & 4.71 & 4.43 & 4.38 \\
\hline & social and economic impacts & 4.86 & 4.57 & 4.44 \\
\hline & management options & 4.71 & 4.31 & 4.44 \\
\hline & $\begin{array}{l}\text { Majority of emerald ash borer (EAB) knowledge comes } \\
\text { from task force involvement }\end{array}$ & 4.29 & 3.86 & 3.56 \\
\hline \multicolumn{5}{|c|}{ Normative Learning } \\
\hline & Normative Score & $4.26(0.51)$ & $3.76(0.60)$ & $3.90(0.50)$ \\
\hline & ...helped me understand the perspective of others & 4.71 & 4.43 & 4.63 \\
\hline & $\begin{array}{l}\text {...has changed my views on which goals should steer } \\
\text { management }\end{array}$ & 4.71 & 3.29 & 3.38 \\
\hline \multicolumn{5}{|c|}{ Relational Learning } \\
\hline & Relational Score & $4.14(0.56)$ & $3.84(0.74)$ & $4.04(0.21)$ \\
\hline & $\begin{array}{l}\text {...has enhanced my cooperation with others that } \\
\text { participate... }\end{array}$ & 4.43 & 4.00 & 4.25 \\
\hline & $\begin{array}{l}\text {...has enhanced my communication with others that } \\
\text { participate... }\end{array}$ & 4.43 & 4.14 & 4.19 \\
\hline & $\begin{array}{l}\text { I have collaborated with individuals I have met on other } \\
\text { projects }\end{array}$ & 4.43 & 3.93 & 3.88 \\
\hline
\end{tabular}

task forces, and members have been withheld at the request of study participants (IRB Protocol \# 1303003715).

\section{RESULTS}

Survey responses indicate that task force members gained knowledge of EAB (cognitive), achieved a better understanding of the perspective of other task force members (normative), and acquired enhanced communication and cooperation with other task force members (relational). Network data confirm that new ties were formed among stakeholders from different levels of government, private firms, and nonprofit organizations. Connections between EAB task forces and ash management on public property were documented. However, task force capacities for learning-in-action network density and management activities differed among the three cases.

\section{Learning}

Scores for cognitive learning were higher than for normative or relational learning (Table 3) and were similar across cases with slightly higher scores in Case 1. Task force members reported increases in their understanding of EAB ecological, social, and economic impacts and management options. When asked if the majority of their knowledge on EAB came from participating in the task force, responses were mixed, which we attribute to initial differences in expertise among task force members. Although members reported normative learning in that task force participation increased their understanding of the perspectives of others, their responses varied about whether the task force increased agreement on ash management goals, likely related to the level of knowledge on ash management options from other sources. There was poor cohesion (low Cronbach's alpha) of normative learning survey items. Relational learning scores were lower in Case 2, which is likely because of the history of collaboration prior to the task force. We interpreted higher relational learning scores in Case 1 and Case 3 to be indicative of the development of new collaborative relationships.

\section{Linking}

In Case 1, in-degree centrality increased 19\% among task force members, from $51 \%$ of members in contact prior to participation in the task force to $70 \%$ afterward (Fig. 1). The task force was the smallest of the cases, consisting of 16 people, representing state agencies, county agencies, municipal staff, citizen volunteers working with a municipality, Cornell Cooperative Extension staff, members of New York State Partnerships for Regional Invasive Species Management (PRISM), and private tree-care firms. The mean number of new members a task force member began communicating with (ODC) was four. When asked who they go to for $\mathrm{EAB}$ information and advice outside of the task force, two task force members listed a university extension associate and two listed a state agency.

Task force members in Case 2 increased their connections from $48 \%$ to $84 \%$ of members having contact with each other (Fig. 2). A very high density of ties can stifle innovation, however, we do not think this is occurred because the survey respondents were part of a larger network of individuals involved with EAB management not directly participating in the task force. The task force included 24 people, representing state, county, and municipal staff, private tree-care firms, private utility personnel, and Cornell Cooperative Extension staff. The mean ODC change was nine. Task force members listed 15 ties (to whom they regularly went to for information and advice on EAB) to university researchers, 7 to federal and state agencies, 9 to county and municipal personnel, and 5 to landscaping and pesticide distributors. 
Fig. 1. Changes in degree centrality (IDC), normalized to group size and network map of emerald ash borer (EAB) task force, Case 1. Note: IDC value refers to mean in-degree centrality.

\section{Case 1}

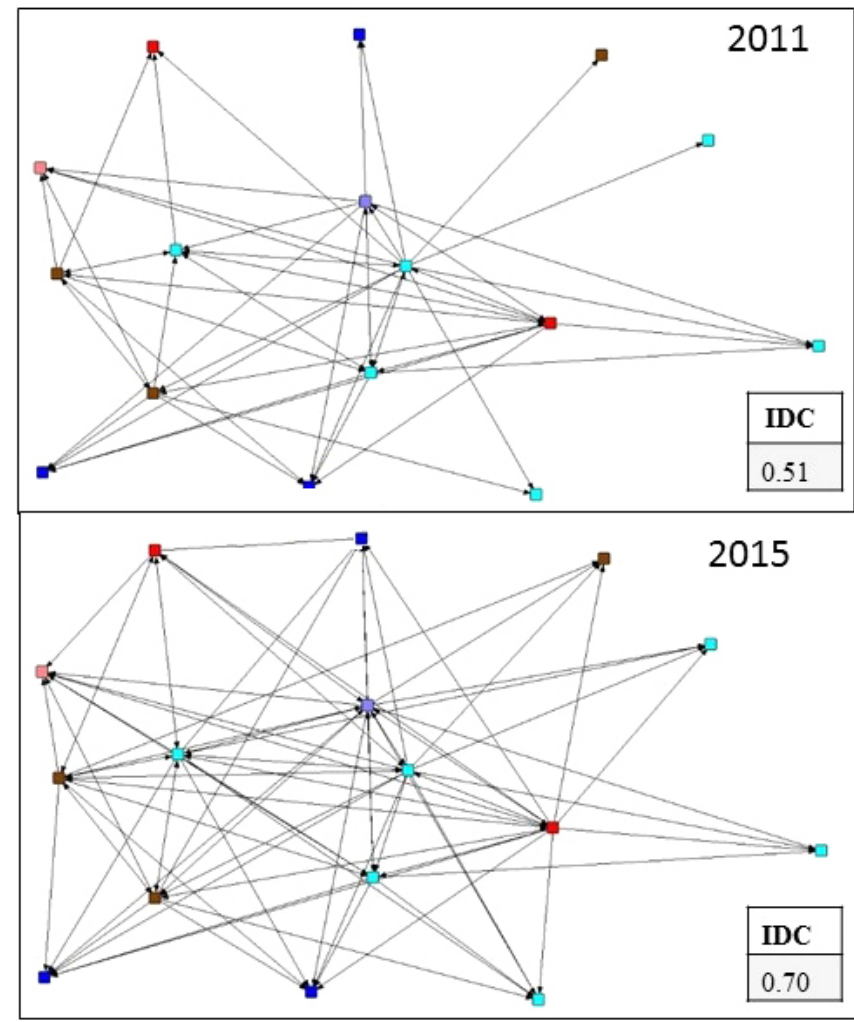

State agency

County Agency Municipality

Extension

Green Industry

Tree Care Firm

Utility Company

Other

Task force members in Case 3 increased their communication network from $40 \%$ to $69 \%$ of task force members (Fig. 3). The task force included 27 individuals, representing all levels of government, Cornell Cooperative Extension, private tree-care firms, and representatives from pesticide-distribution firms. The mean ODC change was eight. Task force members reported 19 ties to landscaping and pesticide firms (to whom they regularly went to for information and advice on EAB), 7 to university researchers, 3 to federal and state agencies, and 1 to county and municipal personnel.

\section{Task force activities and connections to ash management}

Case 1

When EAB was discovered in the county in 2010, the infestation was already large and growing rapidly. A Partnership for Regional
Fig. 2. Changes in degree centrality (IDC), normalized to group size and network map of emerald ash borer (EAB) task force, Case 2. Note: IDC value refers to mean in-degree centrality.

\section{Case 2}

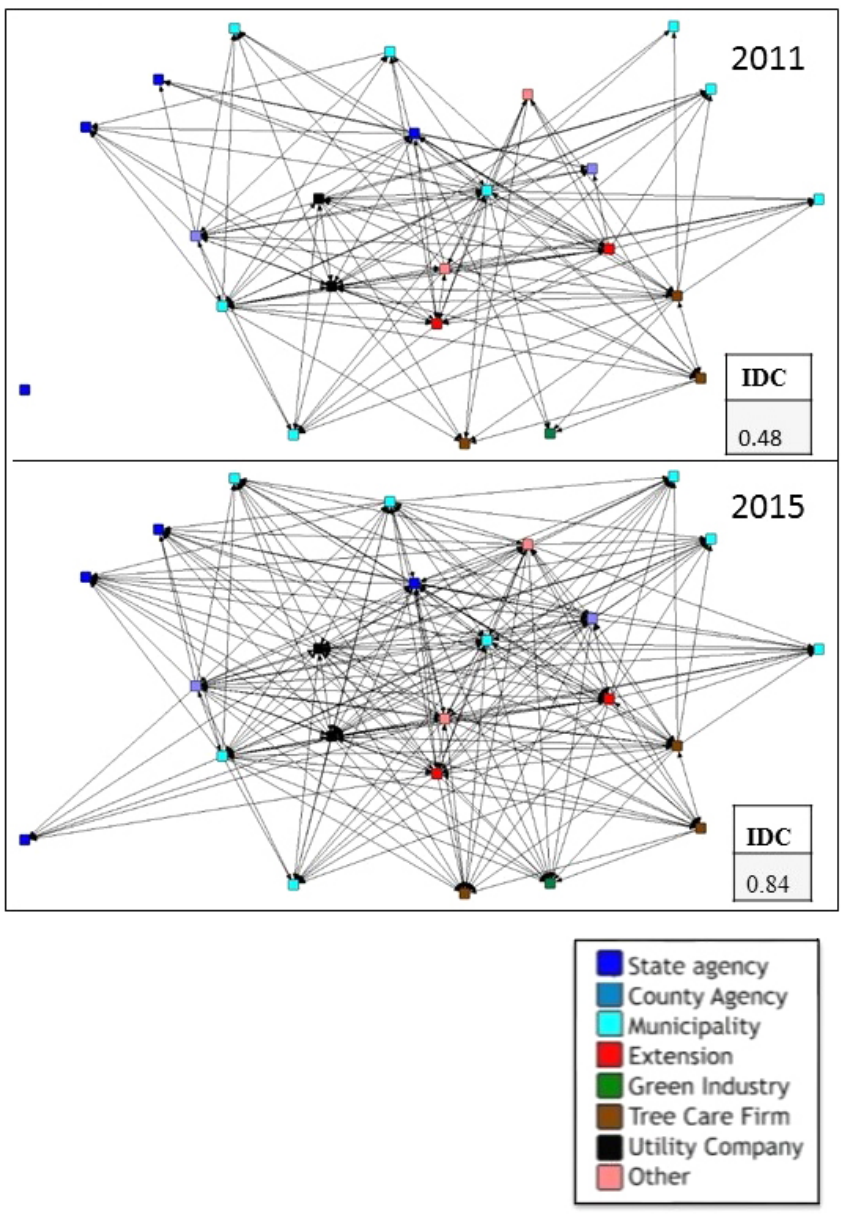

Invasive Species Management (PRISM) coordinator initiated the EAB task force, which met 12 times between 2011 and 2015. Task force activities included: presentations from university extension personnel, discussions of how to mobilize municipalities and homeowners, discussion of the location of declining trees, construction of an EAB educational display, and organization of two workshops for municipal and county personnel responsible for tree management. As one task force member described:

... there were some key people in the task force that really
helped bringing everybody up to speed on the issue, on
the severity of it. I know that [university expert] has been
to several of the task force meetings. It's really been
helpful too to hear what's happening in the different towns
and also on the task force there are a couple of people
from a tree service. Case 1 task force member, 2/6/2016.

By 2015 , the county was experiencing widespread ash mortality. Personnel from the county and one town used the task force for 
Fig. 3. Changes in degree centrality (IDC), normalized to group size and network map of emerald ash borer (EAB) task force, Case 3. Note: IDC value refers to mean in-degree centrality.

\section{Case 3}

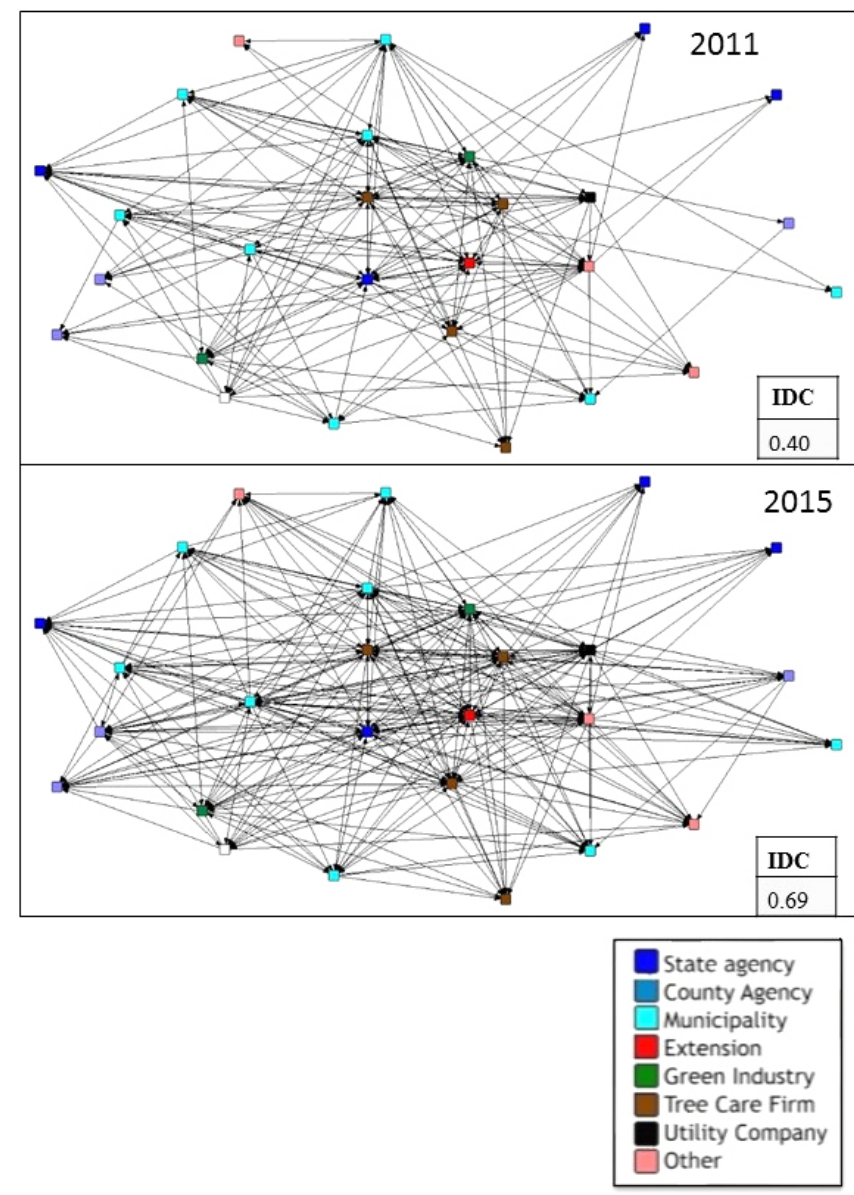

feedback on management plans. Through the sharing of inventory data, task force members discovered that most ash trees were along roads and on private property and there were only a few "high value" street or park trees. State-level agencies responsible for roadside trees were proactive in tree removals. However, execution of county management plans was derailed by lack of personnel and funds. A second municipality removed all of their park ash trees after attending the task force workshops and then used the task force for assistance in complying with wood waste regulations.

Interviewees did not perceive the task force as effective in stimulating comanagement or long-term planning among the county and municipalities. Budget constraints and small staff were identified as insurmountable barriers characteristic of small town and county governments. Interviewees described connections made through the task force that they would use to address future invasive species issues, such as the Asian Longhorned Beetle (ALB):
I think the feeling was going in that there's not much we can to do stop the emerald ash borer.. but we thought it would be very good preparation for ALB... we worked with all kinds of different organizations that would, in my opinion, be needed when ALB would show up if it's not here already. We've set these things in motion now, we know who to call, who we can talk to, who's best to work with. Case 1 task force member, 2/4/2016.

Case 2

A county environmental director learned about EAB and requested that Cornell Cooperative Extension county staff assemble an EAB task force, which met 30 times between 2011 and 2015. Conversations in task force meetings were used to discuss and gain clarity on expected impacts, goals for management, and options available. As one task force leader reported:

Each of these groups [in the task force] brings their own subset of knowledge that everybody else is able to benefit from. So whether it's bringing up a question we didn't know about or it's having access to resources and answers that everybody else needs. Case 2 task force leader, 4/18/13.

When the task force formed in 2012, no EAB infestation was known to exist in the county. The task force set up a cooperative monitoring program to detect $\mathrm{EAB}$ with equipment and expertise from the state agency, a network of trees on county property to be girdled and felled, and volunteer labor coordinated by Cornell Cooperative Extension. This was used to delimit the infested area when it was discovered in 2013 and understand the rate of growth of the infestation in 2014 and 2015.

County managers utilized the task force as a source of advice to execute a tree inventory for their parks and county roads and to develop a 10-year, US\$13.5 million management strategy that incorporated short-term goals (liability and risk management, contractor safety, conservation of high value ash trees) and longterm goals (replanting to enable recovery of the canopy over 100 years). Personnel from utility companies provided technical information on safety standards and equipment. When the management plan was put into action, county managers realized there were no tree-care firms with the necessary safety qualifications. The task force responded by organizing a training for local tree-care companies on how EAB impacts safe treeremoval practices. Following the training, several of the tree-care firms joined the task force, expanding the group of collaborators.

An urban forestry network existed in the county prior to the EAB infestation, including municipal staff, nonprofit organizations, and citizen volunteers who regularly distributed and planted trees throughout the county. As one county manager indicated, these relationships accelerated the collaborative process in the task force:

...there is a long-standing experience, with each other. We know each other's areas of focus, strengths and weaknesses. And you know we all try to respect each other. Case 2 task force member, 2/11/2016.

The pre-existing urban forestry network enabled rapid communication of EAB information to municipalities. Four 
municipalities planned and began to implement tree removals as a result of their participation in the EAB task force, benefitting from the experience of the county. Although participation in the task force waned as goals were met, task force members identified that the relationships they built would be easily activated to deal with a future invasive species or natural resource management issues. As a leader Case 2 task force recounted:

\begin{abstract}
So now we've got ... more capacity and more resiliency, I think, to be able to address these topics, not just Emerald Ash Borer but other things, because we have diversified the range of groups and agencies and businesses being involved, but also what any of those individual groups can do. Case 2 task force leader, 1/27/2016.
\end{abstract}

\section{Case 3}

When EAB was found in this county in 2011, a Partnerships for Regional Invasive Species Management coordinator initiated the EAB task force, which met 20 times between 2011 and 2015. Task force members wrote a mission statement early on, defining the shared purpose of the group as: "a volunteer organization of forestry resource professionals, scientists, natural resource managers, local officials and private citizens assembled to assist local, state and federal EAB programs and to facilitate a science based response to the economic, ecological and public safety impacts of EAB within the forests and communities of [the area]."

In collaboration with the task force, the New York State Department of Conservation conducted a survey of all county municipalities to assess their EAB knowledge, following which the task force organized EAB management workshops for these municipalities. Seven municipalities and the county began managing their ash trees after participation in the task force. Interviewees identified three connections between the task force and these management actions. Partnerships between state, county, and municipal personnel (vertical linking) enabled the task force to reach more municipalities than the agencies would have on their own. Horizontal linking among personnel from different municipalities created opportunities to learn from one another about EAB management issues specific to their context as illustrated in this quote from a task force leader:

Knowing I would be doing one of these [ash management plan], we're asking what are other people are doing, being part of the meeting where everybody gets the update about any activities in the town. Case 3 task force participant, 2/10/2016.

Finally, cooperation on grant writing enabled county and municipal task force participants to access funds for management.

Interviewees described the development of new relationships among county agencies, municipal personnel, and state agencies that would last beyond EAB. As one task force member described:

For some of these communities it has sparked, hopefully a more long-term approach to their overall street tree care. Not just with the ash. And so I think that it has empowered some communities that will be doing more as a result of the ash borer. Case 3 task force member, 2/9/2016.

\section{Results summary}

The three cases represent a natural experiment in ACM. The county in Case 1, a rural county with a low population density, was experiencing an advanced EAB infestation with dead and dying trees prominent along many county roads. Task force members articulated benefits from the information exchanged in task force meetings and reported high levels of learning. However, little management action emerged. The county in Case 2 was urban/suburban with a small, early stage EAB infestation. Although relational learning scores were lower than the other cases, mean IDC values revealed that the network after the task force process was more connected than the other cases. Relationships in place prior to the task force likely explain why complex joint management activities and collective learning-inaction (members devised solutions when they encountered barriers to management) occurred. The members in Case 3, an urban/suburban county with a large, low-intensity EAB infestation, were the least connected prior to the task force. Involvement in the task force increased their communication and cooperation with other task force members; and collaboration among municipal, county, and state participants drew municipalities into the management planning processes, in which they benefited from cooperation on grant writing and sharing experience.

\section{DISCUSSION}

Our original proposition was that a task force could contribute to invasive species management by stimulating learning and linking, two hallmarks of ACM. The case studies in this investigation were geographically close, and the underlying governance structures were similar. In each case, some horizontal and vertical connections existed prior to the task forces. The intervention of EAB task forces was similar as well, however outcomes in terms of management differed across the cases.

\section{The influence of context on adaptive comanagement (ACM) performance}

The result that management outcomes differed among cases suggests that although learning and linking can be introduced to a setting, ACM outcomes are heavily influenced by social and ecological context specific factors. In this study, ecological factors included the size and intensity of the EAB infestation as well as the urgency of the management problem, (i.e., the number of high value, high risk trees in parks or along streets). To untangle the social factors, we used Fabricius et al. (2007)'s broad categories of communities. Case 1 was "powerless" due to the lack of government resources, related to depopulation or low population (cf. Fabricius et al.2007), and the sudden increase in tree mortality. Case 2 had characteristics of "adaptive comanager" communities in which leadership encouraged task force members to utilize polycentric networks (Lee 2003, Folke et al. 2005) and supported proactive, complex planning, and comanagement for EAB that included long-term restoration of the urban canopy. Case 3 also exhibited signs of adaptive comanager communities in which leadership within the task force enabled members to recruit a diverse and elaborate knowledge network around EAB; however, the task force mainly benefited individual members as they 
reacted to $\mathrm{EAB}$ and did not undertake actions that would indicate long-term planning or comanagement. That ACM may perform differently in different places has been seen before (Plummer et al. 2007, Bodin and Crona 2009), thus we have highlighted underlying ecological and social factors that may influence performance: governance capacity, polycentric networks and visionary leadership, and the size and urgency of the management problem.

The result that task force members built new relationships that would extend beyond EAB implies that regardless of initial factors, iterative interactions among stakeholders led to further network formation and adaptive capacity. By utilizing ACM as a strategy toward a management end, impacts can occur at the level of relationships and culture among the participants, making future ACM easier and more productive (Newman and Dale 2005, Plummer et al. 2017). We suggest that knowledge-sharing relationships (cf. Hoffman et al. 2015) that allow for both the flow of information through linking and the production of context specific information through joint learning may form through ACM, however, they may not last if not matched by a supportive institutions and policies (Hahn et al. 2006). Bridging organizations can support networks of knowledge-sharing relationships (Hahn et al. 2006, Olsson et al. 2007, Crona and Parker 2012) and extension systems have the potential to serve as bridging organizations (Hoffman et al. 2015; Nourani, Decker, and Krasny, unpublishedmanuscript). Future research may engage more deeply with how bridging organizations arise and how they support knowledge networks.

\section{Adaptive comanagement (ACM) and invasive species issues}

The result that across cases, task force participants reported high levels of learning about EAB and cited university researchers as important sources of information, suggests that the task forces served as a boundary space between science and policy, supported by the university extension service as a boundary organization (Cash and Moser 2000). Using ACM to increase contact among scientists and policymakers has been documented before (Pohl et al. 2010, Armitage et al. 2011); we extend this thinking into the context of invasive species management. Newly discovered invasive species create a need for rapid and effective research communication. Our findings suggest that ACM initiatives can link land owners, policymakers, and firms to scientists and can provide an ongoing boundary space for stakeholders to translate the scientific information into their own context, potentially narrowing the knowing-doing gap in invasive species management.

Our results suggest that collaboration through ACM can also stimulate the production of new knowledge related to invasive species distribution and the institutional context of management. The result that task force members pooled and produced detailed information on EAB distribution and impacts indicates that ACM may be effective in reducing scale discordance and informational uncertainty (cf. Cash and Moser 2000) for invasive species management. Scale discordance occurs when data produced by researchers are too general to be useful to managers hindering local responses. That individuals working at a neighborhood or municipal level are in a key position to collect information on ecological change has been documented (Colding et al. 2006), but we extend this thinking by suggesting that a regional ACM intervention crossing multiple communities (cf. Plummer et al. 2012) may serve as a platform to compile and analyze the information, making it useable to both managers and researchers.

The result that task force members assembled new knowledge about institutional structures and policy environments suggests that ACM may empower stakeholders to learn about local social and political systems. A deeper consideration of the social and political dimensions of invasive species management has been called for in multiple contexts (Thresher and Kuris 2004, Esler et al. 2010, Marshall et al. 2011, Schelhas et al. 2012, Matzek et al. 2014). The finding that in Cases 2 and 3 task force members considered the responsibilities of institutions to protect the public interest agrees with Fennell et al. (2008) that ACM can be a means of promoting good governance. Generation of information on local institutional contexts is thought to contribute to adaptive capacity through enhancing the fit between ecological and social systems (Hahn et al. 2006). We interpreted research communication, species distribution mapping, and knowledge on institutional context found in this study as cognitive learning because each represent the acquisition or production of new information at an individual and a group level (cf. Baird et al. 2014). However, linking and relational learning was necessary to establish the conditions under which knowledge could be produced.

Our findings of cognitive learning appeared to depend on relational learning and linking within and prior to the formation of the task forces. Contact between task force members and university researchers enabled the task forces to serve as boundary spaces. The result that across cases new relationships were formed and relational learning was reported indicates the task forces served as effective bridging spaces, enabling knowledge pooling among diverse participants. However, the duration of relationships mattered. In Cases 1 and 3, these relationships were being formed through the task force process, whereas in Case 2 they already existed and could be used for more complex comanagement and learning-in-action. The effectiveness of ACM for invasive species may require interventions that build networks in which actors continue to interact over a medium to long time horizon as they collaboratively manage invasive species. Invasive species are often discussed within ecological contexts (e.g., marine invasions, agricultural pests, forest pests), and even in an ecological context, the group of stakeholders do not necessarily overlap. Our results suggest the value of having bridging organizations that can systematically build networks for invasive species management.

Our results on normative learning were inconclusive. There may be confusion within the concept of normative learning because previous studies similarly have not been able to assess or measure it (Haug et al. 2011, Munaretto and Huitema 2012, Baird et al. 2014). A question arises of what changes in norms, views, or paradigms are relevant. Pahl-Wostl (2009) referred to two types of changes that would indicate learning in governance: questioning and revising of governance paradigms (from bureaucratic toward participatory) and changing actor networks (from actors mainly staying in communities of practice to actively seeking advice and opinions outside of their networks, accompanied by a rise in boundary spanners). However, short- 
term ACM initiatives may not stimulate lasting changes in organizational norms. In addition to governance norms, the paradigm of the management problem matters. The EAB has very clear management options and trade-offs involving risk and cost minimization, which may have already been familiar to task force members within a management paradigm. Other issues, such as climate change adaptation, land-use regime changes, or even other invasive species management that require long-term monitoring and action may demand larger normative changes.

\section{Study limitations}

Our study focused on characteristics and outcomes of ACM as a process, and our findings are not an overall portrait of the response to EAB in the counties or a program evaluation. Data limitations included: small sample sizes, missing network data, and potential for recall error in retrospective network questions. To mitigate the impact on the results, we avoided network metrics that were sensitive to missing data and mapped only connections, not frequency of communication. The dramatic nature of EAB and the heavy economic consequences resulted in attention and participation in the task forces that may not exist for other invasive species. The aspects of learning for invasive species management we have identified are exploratory, and further study is needed to identify whether these are applicable across invasive species and management contexts.

\section{CONCLUSION}

Learning and linking were viewed as functions that could be increased through a social intervention for invasive species management. The potential of ACM to improve environmental governance is widely agreed upon, but pathways toward the widespread use of ACM are still unclear. This study suggests that ACM will perform best on urgent management problems and in communities with high governance capacity and adaptive capacity. Networks of knowledge-sharing relationships may prime groups of stakeholders for learning-in-action and comanagement.

Our results also highlight how ACM may catalyze learning relevant for invasive species management by: facilitating communication among researchers and managers, aggregating species distribution information gathered by stakeholders, and producing new insights on the social-political context of management. Universities and federal and state agencies should take the lead in creating and participating in networks of knowledge-sharing partnerships.

Responses to this article can be read online at: http://www.ecologyandsociety.org/issues/responses. php/10327

\section{Acknowledgments:}

We thank all survey respondents, interviewees, and participants in the emerald ash borer task forces, particularly Mark Whitmore, our collaborators in Cornell Cooperative Extension, and the New York State Department of Conservation. We are also grateful to the two anonymous reviewers who provided feedback.

\section{LITERATURE CITED}

Armitage, D., F. Berkes, A. Dale, E. Kocho-Schellenberg, and E. Patton. 2011. Co-management and the co-production of knowledge: learning to adapt in Canada's Arctic. Global Environmental Change 21:995-1004. http://dx.doi.org/10.1016/j. gloenvcha.2011.04.006

Armitage, D., M. Marschke, and R. Plummer. 2008. Adaptive comanagement and the paradox of learning. Global Environmental Change 18:86-98. http://dx.doi.org/10.1016/j.gloenvcha.2007.07.002

Aukema, J. E., B. Leung, K. Kovacs, C. Chivers, K. O. Britton, J. Englin, S. J. Frankel, R. G. Haight, T. P. Holmes, A. M. Liebhold, D. G. McCullough, and B. Von Holle. 2011. Economic impacts of non-native forest insects in the continental United States. PLoS One 6:e24587. http://dx.doi.org/10.1371/journal.pone.0024587

Baird, J., R. Plummer, C. Haug, and D. Huitema. 2014. Learning effects of interactive decision-making processes for climate change adaptation. Global Environmental Change 27:51-63. http:// dx.doi.org/10.1016/j.gloenvcha.2014.04.019

Bayliss, H. R., A. Wilcox, G. B. Stewart, and N. P. Randall. 2012. Does research information meet the needs of stakeholders? Exploring evidence selection in the global management of invasive species. Evidence and Policy: A Journal of Research, Debate and Practice 8:37-56. http://dx.doi.org/10.1332/1744264$12 \times 620128$

Berkes, F. 2009. Evolution of co-management: role of knowledge generation, bridging organizations and social learning. Journal of Environmental Management 90:1692-1702. http://dx.doi.org/10.1016/ j.jenvman.2008.12.001

Bodin, Ö., and B. I. Crona. 2009. The role of social networks in natural resource governance: what relational patterns make a difference? Global Environmental Change 19:366-374. http://dx. doi.org/10.1016/j.gloenvcha.2009.05.002

Bodin, Ö., B. Crona, and H. Ernstson. 2006. Social networks in natural resource management: what is there to learn from a structural perspective? Ecology and Society 11(2):r2. http://www. ecologyandsociety.org/vol11/iss2/resp2/

Borgatti, S., M. Everett, and L. Freeman. 2002. Ucinet 6 for Windows: software for social network analysis. Analytic Technologies, Harvard, Massachusetts, USA.

Buckley, Y. M. 2008. The role of research for integrated management of invasive species, invaded landscapes and communities. Journal of Applied Ecology 45:397-402. http://dx. doi.org/10.1111/j.1365-2664.2008.01471.X

Burt, R. S. 2003. The social capital of structural holes. Pages 210-221 in M. F. Guillen, R. Collins, P. England, and M. M, editors. New directions in economic sociology. Russell Sage Foundation, New York, New York, USA. [online] URL: https:// faculty.chicagobooth.edu/ronald.Burt/research/files/SCSH.pdf

Cash, D. W., W. N. Adger, F. Berkes, P. Garden, L. Lebel, P. Olsson, L. Pritchard, and O. Young. 2006. Scale and cross-scale dynamics: governance and information in a multilevel world. Ecology and Society 11(2):8. http://dx.doi.org/10.5751/ES-01759-110208

Cash, D. W., and S. C. Moser. 2000. Linking global and local scales: designing dynamic assessment and management processes. 
Global Environmental Change 10:109-120. http://dx.doi. org/10.1016/S0959-3780(00)00017-0

Colding, J., J. Lundberg, and C. Folke. 2006. Incorporating greenarea user groups in urban ecosystem management. $A M B I O$ 35:237-244. http://dx.doi.org/10.1579/05-A-098R.1

Cook, D. C., S. Liu, B. Murphy, and W. M. Lonsdale. 2010. Adaptive approaches to biosecurity governance. Risk Analysis 30:1303-1314. http://dx.doi.org/10.1111/j.1539-6924.2010.01439. $\underline{\mathrm{x}}$

Costenbader, E., and T. W. Valente. 2003. The stability of centrality measures when networks are sampled. Social Networks 25:283-307. http://dx.doi.org/10.1016/S0378-8733(03)00012-1

Crona, B. I., and J. N. Parker. 2011. Network determinants of knowledge utilization. Science Communication 33:448-471. http:// dx.doi.org/10.1177/1075547011408116

Crona, B. I., and J. N. Parker. 2012. Learning in support of governance: theories, methods, and a framework to assess how bridging organizations contribute to adaptive resource governance. Ecology and Society 17(1):32. http://dx.doi. org/10.5751/ES-04534-170132

Donlan, C. J., and P. S. Martin. 2004. Role of ecological history in invasive species management and conservation. Conservation Biology 18:267-269. http://dx.doi.org/10.1111/j.1523-1739.2004.00101. $\underline{\mathrm{x}}$

Ensor, J., and B. Harvey. 2015. Social learning and climate change adaptation: evidence for international development practice. Wiley Interdisciplinary Reviews: Climate Change 6:509-522. http://dx.doi.org/10.1002/wcc.348

Epanchin-Niell, R. S., M. B. Hufford, C. E. Aslan, J. P. Sexton, J. D. Port, and T. M. Waring. 2010. Controlling invasive species in complex social landscapes. Frontiers in Ecology and the Environment 8:210-216. http://dx.doi.org/10.1890/090029

Esler, K. J., H. Prozesky, G. P. Sharma, and M. McGeoch. 2010. How wide is the "knowing-doing" gap in invasion biology? Biological Invasions 12:4065-4075. http://dx.doi.org/10.1007/ s10530-010-9812-X

Fabricius, C., C. Folke, G. Cundill, and L. Schultz. 2007. Powerless spectators, coping actors, and adaptive comanagers: a synthesis of the role of communities in ecosystem management. Ecology and Society 12(1):29. http://dx.doi.org/10.5751/ES-02072-120129

Fennell, D., R. Plummer, and M. Marschke. 2008. Is adaptive comanagement ethical? Journal of Environmental Management 88:62-75. http://dx.doi.org/10.1016/j.jenvman.2007.01.020

Folke, C., T. Hahn, P. Olsson, and J. Norberg. 2005. Adaptive governance of social-ecological systems. Annual Review of Environment and Resources 30:441-473. http://dx.doi.org/10.1146/ annurev.energy.30.050504.144511

Hahn, T., P. Olsson, C. Folke, and K. Johansson. 2006. Trustbuilding, knowledge generation and organizational innovations: the role of a bridging organization for adaptive comanagement of a wetland landscape around Kristianstad, Sweden. Human Ecology 34:573-592. http://dx.doi.org/10.1007/s10745-006-9035$\underline{\mathrm{Z}}$
Haug, C., D. Huitema, and I. Wenzler. 2011. Learning through games? Evaluating the learning effect of a policy exercise on European climate policy. Technological Forecasting and Social Change 78(6):968-981. http://dx.doi.org/10.1016/j.techfore.2010.12.001

Hanneman, R., and M. Riddle. 2005. Introduction to social network methods. University of California, Riverside, Riverside, California, USA. [online] URL: http://faculty.ucr.edu/ hanneman/nettext/

Hoffman, M., M. Lubell, and V. Hillis. 2015. Network-smart extension could catalyze social learning. California Agriculture 69:113-122. http://dx.doi.org/10.3733/ca.E.v069n02p113

Holling, C. S. 1978. Adaptive environmental assessment and management. John Wiley and Sons, Chichester, UK.

Lauber, T. B., and T. L. Brown. 2006. Learning by doing: policy learning in community-based deer management. Society and Natural Resources 19:411-428. http://dx.doi.org/10.1080/08941920600561066

Lavoie, C., and J. Brisson. 2015. Training environmental managers to control invasive plants: acting to close the knowing-doing gap. Invasive Plant Science and Management 8:430-435. http://dx.doi. org/10.1614/IPSM-D-15-00033.1

Lebel, L., T. Grothmann, and B. Siebenhüner. 2010. The role of social learning in adaptiveness: insights from water management. International Environmental Agreements: Politics, Law and Economics 10:333-353. http://dx.doi.org/10.1007/s10784-010-9142-6

Lee, K. N. 1999. Appraising adaptive management. Conservation Ecology 3(2):3. http://dx.doi.org/10.5751/ES-00131-030203

Lee, M. 2003. Conceptualizing the new governance: a new institution of social coordination. Page 26 in Institutional Analysis and Development Mini-Conference, Bloomington, Indiana, USA. Indiana University, Bloomington, Indiana, USA. [online] URL: http://citeseerx.ist.psu.edu/viewdoc/download;jsessionid=905CC522C3ECE5EE7E7475E139278C2D?doi=10.1.1.202.1474\&rep= rep1\&type $=$ pdf

Marsden, P. V. 1990. Network data and measurement. Annual Review of Sociology 16:435-463. http://dx.doi.org/10.1146/ annurev.so.16.080190.002251

Marshall, N. A., M. Friedel, R. D. van Klinken, and A. C. Grice. 2011. Considering the social dimension of invasive species: the case of buffel grass. Environmental Science and Policy 14:327-338. http://dx.doi.org/10.1016/j.envsci.2010.10.005

Matzek, V., J. Covino, J. L. Funk, and M. Saunders. 2014. Closing the knowing-doing gap in invasive plant management: accessibility and interdisciplinarity of scientific research. Conservation Letters 7:208-215. http://dx.doi.org/10.1111/ conl.12042

McClenachan, L., G. O'Connor, and T. Reynolds. 2015. Adaptive capacity of co-management systems in the face of environmental change: the soft-shell clam fishery and invasive green crabs in Maine. Marine Policy 52:26-32. http://dx.doi.org/10.1016/j. marpol.2014.10.023

McFarland, D. A., S. Messing, M. Nowak, and S. J. Westwood. 2010. Social network analysis labs in R. Stanford University, 
Stanford, California, USA. [online] URL: https://sna.stanford. edu/rlabs.php

Miller, J. H., and J. Schelhas. 2008. Collaborative adaptive restoration: a key concept in invasive plant management. Pages 251-266 in R. K. Kohli, S. Jose, H. P. Singh, and D. R. Batish, editors. Invasive plants and forest ecosystems. CRC Press, Boco Raton, Florida, USA.

Munaretto, S., and D. Huitema. 2012. Adaptive comanagement in the Venice lagoon? An analysis of current water and environmental management practices and prospects for change. Ecology and Society 17(2):19. http://dx.doi.org/10.5751/ ES-04772-170219

Newman, L., and A. Dale. 2005. The role of agency in sustainable local community development. Local Environment 10:477-486. http://dx.doi.org/10.1080/13549830500203121

Olsson, P., C. Folke, V. Galaz, T. Hahn, and L. Schultz. 2007. Enhancing the fit through adaptive co-management: creating and maintaining bridging functions for matching scales in the Kristianstads Vattenrike Biosphere Reserve, Sweden. Ecology and Society 12(1):28. http://dx.doi.org/10.5751/ES-01976-120128

Olsson, P., C. Folke, and T. Hahn. 2004. Social-ecological transformation for ecosystem management: the development of adaptive comanagement of a wetland landscape in southern Sweden. Ecology and Society 9(4):2. http://dx.doi.org/10.5751/ ES-00683-090402

Pahl-Wostl, C. 2009. A conceptual framework for analysing adaptive capacity and multi-level learning processes in resource governance regimes. Global Environmental Change 19:354-365. http://dx.doi.org/10.1016/j.gloenvcha.2009.06.001

Plummer, R., J. Baird, A. Dzyundzyak, D. Armitage, Ö. Bodin, and L. Schultz. 2017. Is adaptive co-management delivering? Examining relationships between collaboration, learning and outcomes in UNESCO biosphere reserves. Ecological Economics 140:79-88. http://dx.doi.org/10.1016/j.ecolecon.2017.04.028

Plummer, R., B. Crona, D. R. Armitage, P. Olsson, M. Tengö, and O. Yudina. 2012. Adaptive comanagement: a systematic review and analysis. Ecology and Society 17(3):11. http://dx.doi. org/10.5751/ES-04952-170311

Plummer, R., J. FitzGibbon, and D. Armitage. 2007. Connecting adaptive co-management, social learning and social capital through theory and practice. Pages 38-61 in D. Armitage, F. Berkes, and N. Doubleday, editors. Adaptive co-management: collaboration, learning and multi-level governance. UBC Press, Vancouver, British Columbia, Canada. [online] URL: https:// www.ubcpress.ca/asset/9067/1/9780774813839.pdf

Plummer, R., L. Shultz, D. Armitage, Ö. Bodin, B. Crona, and J. Baird. 2014. Developing a diagnostic approach for adaptive comanagement and considering its implementation in biosphere reserves. Beijer Institute of Ecological Economics Discussion Paper 245. Stockholm Resilience Centre, Stockholm, Sweden.

Pohl, C., S. Rist, A. Zimmermann, P. Fry, G. S. Gurung, F. Schneider, C. I. Speranza, B. Kiteme, S. Boillat, E. Serrano, G. H. Hadorn, and U. Wiesmann. 2010. Researchers' roles in knowledge co-production: experience from sustainability research in Kenya, Switzerland, Bolivia and Nepal. Science and Public Policy 37:267-281. http://dx.doi.org/10.3152/030234210X496628

Prell, C. 2011. Some basic structural characteristics of networks. Pages 29-43 in Ö. Bodin and C. Prell, editors. Social networks and natural resource management: uncovering the social fabric of environmental governance. Cambridge University Press, Cambridge, UK.

Reed, M. S., A. C. Evely, G. Cundill, I. Fazey, J. Glass, A. Laing, J. Newig, B. Parrish, C. Prell, C. Raymond, and L. C. Stringer. 2010. What is social learning? Ecology and Society 15(4):r1. http:// dx.doi.org/10.5751/ES-03564-1504r01

Rodela, R. 2011. Social learning and natural resource management: the emergence of three research perspectives. Ecology and Society 16(4):30. http://dx.doi.org/10.5751/ ES-04554-160430

Saldana, J. 2013. The coding manual for qualitative researchers. Sage, Thousand Oaks, California, USA.

Schelhas, J., J. H. Miller, and J. Chambers. 2012. Non-native plants and adaptive collaborative approaches to ecosystem restoration in the United States. Pages 163-186 in J. Stanturf, P. Madsen, and D. Lamb, editors. A goal-oriented approach to forest landscape restoration. Springer, Dordrecht, the Netherlands. http://dx.doi. org/10.1007/978-94-007-5338-9 8

Smitley, D., T. Davis, and E. Rebek. 2008. Progression of ash canopy thinning and dieback outward from the initial infestation of emerald ash borer (Coleoptera: Buprestidae) in Southeastern Michigan. Journal of Economic Entomology 101:1643-1650. http://dx.doi.org/10.1093/jee/101.5.1643

Thresher, R. E., and A. M. Kuris. 2004. Options for managing invasive marine species. Biological Conservation 6:295-300. http:// dx.doi.org/10.1023/B:BINV.0000034598.28718.2e

Walker, B., S. Carpenter, J. Anderies, N. Abel, G. Cumming, M. Janssen, J. Norberg, G. D. Peterson, and R. Pritchard. 2002. Resilience management in social-ecological systems : a working hypothesis for a participatory approach. Conservation Ecology 6 (1):14. http://dx.doi.org/10.5751/ES-00356-060114

Wollenberg, E., R. Iwan, G. Limberg, M. Moeliono, S. Rhee, and M. Sudana. 2007. Facilitating cooperation during times of chaos: spontaneous orders and muddling through in Malinau District, Indonesia. Ecology and Society 12(1):3. http://dx.doi. org/10.5751/ES-01943-120103

Yin, R. K. 2003. Case study research design and methods. Third edition. Sage, Thousand Oaks, California, USA. 
Appendix I: Interview Guide and Survey Instruments

Interview Guide

Objectives
A. To determine key informant's perceptions of the outcomes of the EAB task forces
B. To gain information from key informants on municipal and county ash management plans and actions
C. To investigate links between practices and activities undertaken by the EAB task force and outcomes

Questions:

\begin{tabular}{|c|c|}
\hline Objective & Question \\
\hline Opening and Background & How did you become involved with the EAB task force? \\
\hline $\begin{array}{l}\text { To determine key } \\
\text { informant's perceptions } \\
\text { of the outcomes of the } \\
\text { EAB task forces }\end{array}$ & $\begin{array}{l}\text { This kind of task force can have a variety of products and } \\
\text { outcomes. I will be going through a list of possible outcomes from } \\
\text { the EAB task force. I would appreciate your input on each and } \\
\text { then at the end you can add in any outcomes or impacts I have } \\
\text { missed. } \\
\text { Provide a list of municipalities, go down the list and solicit } \\
\text { information on: } \\
\text { Ash trees REMOVED by MUNICIPALITIES } \\
\text { Ash trees TREATED with pesticides by MUNICIPALITIES } \\
\text { Ash trees REMOVED by COUNTY } \\
\text { Ash trees TREATED by COUNTY }\end{array}$ \\
\hline \multirow[t]{2}{*}{$\begin{array}{l}\text { To investigate links } \\
\text { between practices and } \\
\text { activities undertaken by } \\
\text { the EAB task force and } \\
\text { outcomes }\end{array}$} & $\begin{array}{l}\text { "You said the following actions were taken: xx, yy, zzz, now I } \\
\text { would like to go through each one and ask if you think the task } \\
\text { force had an influence and if the TF did....how the TF might have } \\
\text { influenced the outcomes. } \\
\text { - How did that happen? What are the links? }\end{array}$ \\
\hline & In addition to the tangible management plans and actions that you \\
\hline
\end{tabular}




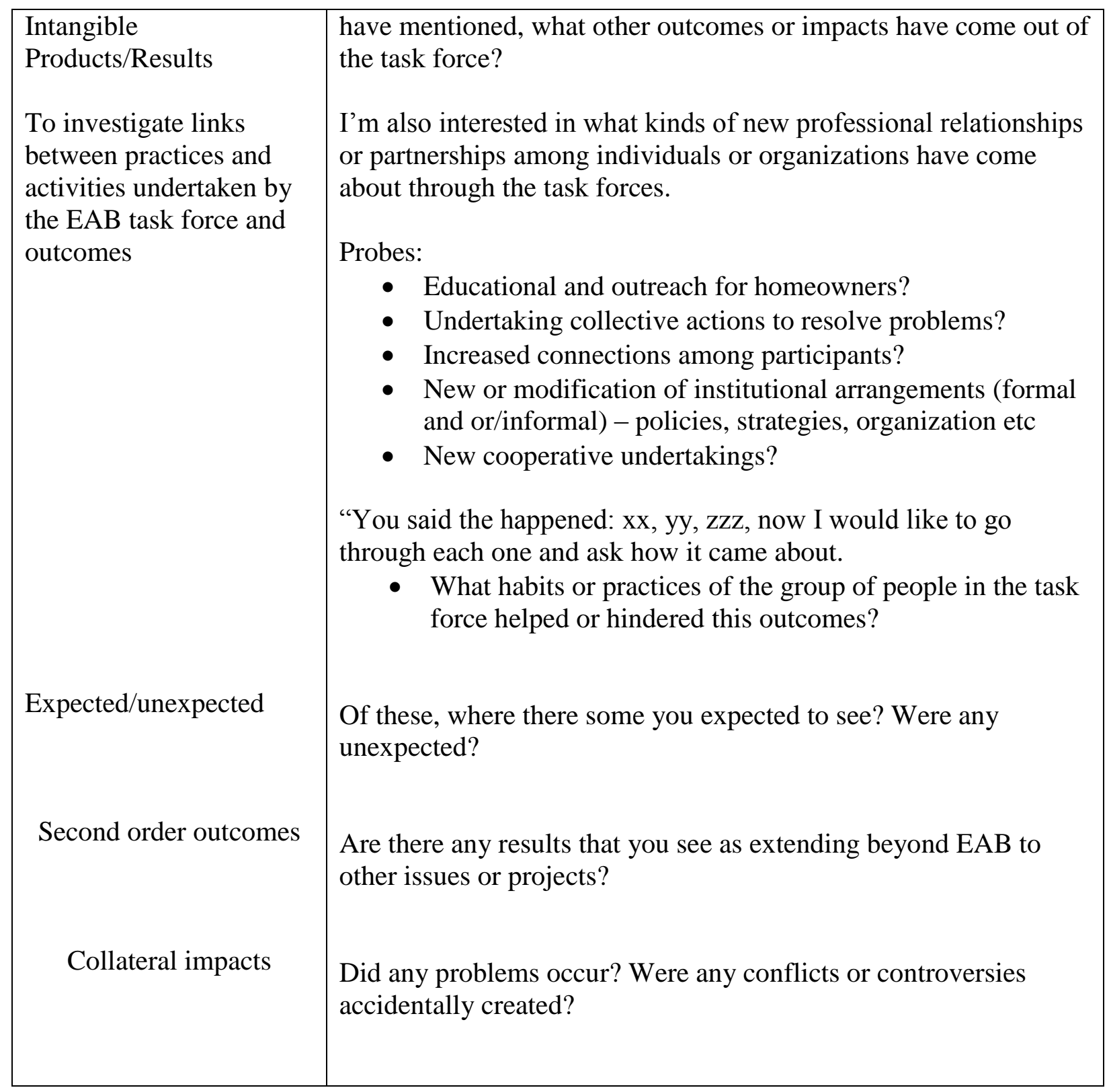




\section{Survey Instruments}

Q0 Welcome to the Emerald Ash Borer Task Force Project Survey This questionnaire will take about 10 minutes. Your answers will help us to understand how collaborative groups, such as the Emerald Ash Borer task forces have contributed to timely and appropriate management of ash resources in the face of impacts from the emerald ash borer and other invasive species. In the questions below, you will be asked about your participation in the EAB task force, and your communication with other members of the task force. You will be asked for your name and professional affiliation as part of the survey. Your name will not appear in any reports or presentations, and the information you provide will be kept confidential in a password protected database. We will share the findings of the study with the EAB task forces via Webex which may help you in your conservation and outreach efforts. Your participation is completely voluntary and we do not anticipate any risks to you. You may skip any questions that you do not want to answer.

Q1 What is your name?

Q2 What agency or organization are you affiliated with?

Q3 What is your position in the agency or organization?

Q4 The following questions will help us to understand the collaboration between government and the private sector and among levels of government that has gone on around the management of EAB. We are interested in how existing professional relationships and networks have supported the work of the Emerald Ash Borer task forces, and if new communication and collaboration has been established. For each person on the list below, please indicate how often you have had contact (in person, over the phone or via email) with him or her based on the following categories:

a) "How frequently were you in contact with this person below PRIOR TO becoming involved with the Emerald Ash Borer task force?"

b) "How frequently are you in contact with this person in the LAST YEAR?" Please select an answer from the dropdown list for both questions.

\section{How frequently were you in contact with this person PRIOR TO}

your involvement with the Emerald Ash Borer task force?

\begin{tabular}{|c|c|c|c|c|c|}
\hline $\begin{array}{c}\text { Several } \\
\text { times a } \\
\text { week } \\
(1)\end{array}$ & $\begin{array}{c}\text { Several } \\
\text { times a } \\
\text { month } \\
(2)\end{array}$ & $\begin{array}{c}\text { Several } \\
\text { times a } \\
\text { year } \\
(3)\end{array}$ & $\begin{array}{c}\text { Once } \\
\text { a } \\
\text { year } \\
(4)\end{array}$ & $\begin{array}{l}\text { Never } \\
(5)\end{array}$ & $\begin{array}{l}\text { Not applicable - } \\
\text { that's me (6) }\end{array}$ \\
\hline 0 & 0 & 0 & 0 & 0 & 0 \\
\hline
\end{tabular}




How frequently are you in contact with this person in
\begin{tabular}{|c|c|c|c|c|c|}
\hline $\begin{array}{c}\text { Several } \\
\text { the LAST YEAR? }\end{array}$ & $\begin{array}{c}\text { Several } \\
\text { times a }\end{array}$ & $\begin{array}{c}\text { Several } \\
\text { times a }\end{array}$ & Once & & Not \\
timees a & a & Never & applicable \\
$(1)$ & month & year & year & $(5)$ & - that's \\
0 & 0 & $(3)$ & $(4)$ & & me (6) \\
\hline
\end{tabular}

Q5 Please think about organizations or individuals not listed above that you go to for information, advice, support, or help on EAB or ash management. Enter the name of the individual or organization and how frequently you have been in contact with them in person, over the phone or via email (up to 10 individuals or organizations).

\begin{tabular}{|c|c|c|c|c|}
$\begin{array}{c}\text { Name of individual } \\
\text { or organization }\end{array}$ & \multicolumn{4}{|c|}{ How frequently have you had contact with this individual or } \\
organization related to EAB?
\end{tabular}

Q6 Please think about organizations or individuals not listed above to whom you have given information, advice, support or help on EAB or ash management. Enter the name of the individual or organization and how frequently you have been in contact with them (up to 10 individuals or organizations).

\begin{tabular}{|c|c|c|c|c|}
$\begin{array}{c}\text { Name of individual } \\
\text { or organization }\end{array}$ & \multicolumn{4}{|c|}{ How frequently have you had contact with this individual } \\
& or organization related to EAB? \\
\hline & $\begin{array}{c}\text { Several times } \\
\text { a week (1) }\end{array}$ & $\begin{array}{c}\text { Several times } \\
\text { a month (2) }\end{array}$ & $\begin{array}{c}\text { Several times } \\
\text { a year (3) }\end{array}$ & Once a \\
& 0 & 0 & year (4) \\
& 0 & 0 & O \\
\hline
\end{tabular}


Q22 Below, we have listed categories of activities common in areas dealing with the emerald ash borer. Please consider each category and in the space below list or describe activities that you have participated in. Education and outreach activities (ex. giving a presentation on EAB, manning a table at a public event, preparing a pamphlet or other educational material)

Q23 Activities related to monitoring (ex. examination of ash trees for signs and symptoms of $\mathrm{EAB}$, delimitation of infested areas)

Q24 Activities related to management and planning (e.g., management planning, ash tree inventories, tree removal or treatment)

Q10 In this section of the questionnaire we are interested in understanding how the emerald ash borer task force has influenced your work. Please think about your participation in EAB task force meetings, at statement below, please indicate the extent to which you agree or disagree: (Check the appropriate box on the scale below from strongly disagree to strongly agree) educational events put on by the EAB task force or in other interactions you feel are related to your involvement with the $\mathrm{EAB}$ task force. What have you come away with from participating?

Please indicate your agreement or disagreement to the following statements. (strongly disagree, disagree, neutral, agree, strongly agree)

My understanding of the ecological impacts of emerald ash borer has increased.

My understanding of the social and economic impacts of EAB have increased.

My understanding of the options and timeline for management of ash trees has increased.

A majority of my current knowledge about EAB comes from my involvement with the EAB task force process.

The EAB task force has helped me understand the perspective of others participating in the task force.

The EAB task force has become more important to my work over time.

My experience with the EAB task force process has led me to participate in new or surprising projects.

My views are similar to those of others involved in the $\mathrm{EAB}$ task force.

Over time, the process has changed my view on which goals should steer the management ash trees in the area. 
My involvement has enhanced my cooperation with other individuals and groups/organizations that participate in the EAB task force.

My involvement enhanced my cooperation with other individuals and groups/organizations that don't directly participate in the EAB task force.

My involvement has enhanced my communication with other individuals and groups/organizations within the EAB task force.

My involvement has enhanced my communication with other individuals and groups/organizations outside the EAB task force.

I have collaborated with individuals I have met through the EAB task force on other projects.

Q25 This is the end of the survey. Please share any additional information or comments you have about the EAB task force or the process of dealing with EAB in your area in the space below. 